\title{
Biosorption of Azo Dye (Maxilon Red and Everzol Red) on to natural and modified waste sludge
}

\author{
Sarioglu (Cebeci) M. ${ }^{*}$ and Aşkal M. \\ Cumhuriyet University/Department of Environmental Eng., Sivas-58140, TURKEY \\ Received: 14/05/2017, Accepted: 14/11/2017, Available online: 01/12/2017 \\ *to whom all correspondence should be addressed: e-mail: sarioglu@cumhuriyet.edu.tr
}

\begin{abstract}
A wide range of technologies has been developed for the removal of dyes from wastewaters to decrease their environmental impact. Wastewater containing dyes is generally treated using more than one process such as adsorption/biosorption. In this study, effects of initial $\mathrm{pH}$ (2-8), initial azo dye concentration (Co:25-200 mg/l), contact time (tc:2.5-1440 $\mathrm{min}$ ) and amount of waste sludge (m:1-15 g/l) were studied by natural and modified dried waste aerobic sludge (WS) in a lab-scale batch study and also optimized by employing response surface methodology (RSM)-Box-Behnken Model for Maxilon Red GRL(MRGRL) and Everzol Red (ER) removal from wastewaters. The optimum experimental conditions were found to be $\mathrm{pH}=5, \mathrm{Co}=112.5 \mathrm{mg} / \mathrm{l}, \mathrm{tc}=180 \mathrm{~min}$. and $\mathrm{m}=$ $15 \mathrm{~g} / \mathrm{l}$ for dyes and MRGRL and ER removal was determined as about $97 \%$ and $95.85 \%$, respectively. The results clearly showed that amount of WS and contact time are the most important parameters for color removal.
\end{abstract}

FTIR and SEM (scanning electron microscope) images were used to understand morphology and structural character of WS and after biosorption process. D-R biosorption isotherm model was used in order to determine type of biosorption mechanism. The $E$ value of $D-R$ isotermisotherm model was found to be 7.071 for both dye. Pseudo-second order and intraparticle diffusion (Weber-Morris) models were suitable for biosorption kinetics. 0,1 M HCl and $\mathrm{NaOH}$ were used for desorption studies. Effect of ionic strength $(\mathrm{NaCl})$ was not observed between $0,5-1 \mathrm{~mol} / \mathrm{L} \mathrm{NaCl}$ on to biosorption efficiency. WS (biowaste), Natural or modified, one of the low-cost biosorbent, can be used for removal of azo dye from wastewaters.

Keywords: Azo dye, wastewater, biosorption, waste sludge, RSM, SEM and FTIR

\section{Introduction}

Dyes are produced in several industries such as textiles, cosmetics, papers, leather, pharmaceutial, food processing and dye manufacturing industres. The textile dyeing and finishing industry has a significant amount of water pollution to environment. Turkey has a lot of textile industries. Generally, conventional biological treatment processes have some difficulties for degradation of nonbiodegradable compounds and many dyes. Dye bearing wastewaters have high COD and color. Common groups of dyes in textile industry, azo dyes (60-70\%), are charactarized by their typical $-\mathrm{N}=\mathrm{N}$ - nature.

Synthetic dyes are used in various industrial dyeing and printing processes. Textile industry is the largest user of synthetic dyes (Murugesan et al., 2007).Azo dyes are mostly used in textile dyeing (Zollinger, 1991; Wu et al., 1998; Beydilli et al., 2000; Sharma et al., 2009) Azo dyes are readily decolorized by degradation under anaerobic conditions, anaerobic wastewater treatment systems are superior to aerobic methods for azo dye removal (Sarioglu et al., 2007). Some dyes and their breakdown products may be toxic towards living organisms. Therefore various methods, including biological processes, combined chemical and biochemical processes, chemical oxidation, adsorption, coagulation and membrane treatments have been used for removal of dyes from water and wastewaters.

Biosorption process is one of the effective and process for treatment of dye-bearing wastewaters. Therefore, lowcost biosorbents such as yeast, algae, bacteria and biowaste materials were used for dye removal from wastewaters (Volesky, 1990; Aksu, 2005; Wang and Chen, 2006). Powdered activated sludge, sewage sludge were studied for removal of these pollutants from aqueous solutions in a batch and continuous system by several researchers (Aksu, 2005, Kargi and Ozmihci, 2004; Mckay et al., 1986). An activated sludge process, the one of the common aerobic biological wastewater systems is widely used in the world and produce huge amount of waste sludge. Some of the waste activated sludge (WS) after dried can be used for biosorption process in order to reduce sludge disposal. Application of response surface methodology (RSM) is used to optimize the design and reduce the cost of expensive analysis methods. Most importantly, modeling reduces the time and human effort involved in carrying out real experiments and minimizes the experimental errors. RSM provides maximum information of the results out of less number of experiments. Moreover, the graphical results are user friendly, easy to understand. RSM is an experimental 
approach to identify the optimum conditions for the systems (Yetilmezsoy et al., 2009).

In this study, effects of initial $\mathrm{pH}$ (2-8), initial azo dye concentration (Co:25-200 mg/l), contact time (tc:2.5-1440 $\mathrm{min}$ ) and amount of waste sludge ( $\mathrm{m}: 1-15 \mathrm{~g} / \mathrm{l})$ were studied for removal from wastewaters by dried waste activated sludge (WS) in a lab.-scale batch study. Desorption and ionic strength effects was studied using $0,1 \mathrm{M} \mathrm{NaOH}, \mathrm{HCl}$ and $\mathrm{NaCl}$, respectively. Batch experiments were performed with and without optimization as a function of $\mathrm{pH}$, initial dye concentration (Co), contact time (tc) and biosorbent amount $(\mathrm{m})$ using a four factor, three level Box- Behnken experimental. During the optimization study, model results was good at observed experimental data

\section{Materials and methods}

\subsection{Waste activated sludge (WS) characterization}

Waste activated sludge (WS) was taken from the Cumhuriyet University wastewater treatment plant consisting of mechanical treatment, an activated sludge unit and a belt filter press. Sludge samples were collected from return activated sludge unit. The sample was ground and sieved to $0.063-0.125 \mathrm{~mm}$ particle size and then washed with distilled water to remove any nonadhesive impurities and small particles, and then dried at $103{ }^{\circ} \mathrm{C}$ for $24 \mathrm{~h}$ to remove moisture. The waste sludge is referred to as dried waste sludge (WS) in the following sections.

Infrared analysis was conducted on a Mattson 1000 FT-IR spectrometer(UK). FT-IRspectrophotometer (Mattson 1000, UK) analysis was used to characterize the structural change on the sorbent after its sorption with dyes Pellets of samples were prepared by mixing with $\mathrm{KBr}$ and spectra were obtained as a resolution of $4 \mathrm{~cm}^{-1}$. The spectral range covered was $4000-400 \mathrm{~cm}^{-1}$. Scanning electron microscope (SEM) was used to obtain morfology of biomass.

\subsection{Dye solution}

Dyes were supplied from a textile factory in Bursa, Turkey and was of commercial quality. Table 1 shows the structrues and properties of Maxilon Red GRL (MRGRL). $\lambda$ max of (MRGRL) and EVERZOL Red (ER) was determined in an aqueous medium by using a scanning UV-vis spectrophotometer.

Table 1. Properties of MRGRL

\begin{tabular}{cc}
\hline Color index & Maxilon Red GRL \\
\hline Type & Cationic \\
\hline Sulphonic group & None \\
\hline Azo group & 1 \\
\hline$\lambda_{\max }$ & 530 \\
\hline $\mathrm{pH}$ range & $2-12$ \\
\hline$*$ Molecular weight $(\mathrm{g} / \mathrm{mol})$ & 322 \\
\hline$*$ With $(\mathrm{nm})$ & 1.3 \\
\hline *Depth $(\mathrm{nm})$ & 0.74 \\
\hline *Thickness $(\mathrm{nm})$ & 0.63 \\
\hline$*$ Associated counter ions are not included.
\end{tabular}

The ER dye has a reactive, and azo grup. $\lambda$ max of this dye is 540 .

\subsection{Batch experimental studies}

A stock solution of $1000 \mathrm{mg} / \mathrm{l}$ of MR GRL and ER was prepared by dissolving in distilled water. Biosorption onto WS experiments were achieved in $250 \mathrm{ml}$ capacity of Erlenmeyer with $100 \mathrm{ml}$ working volume for different contact times by using shaker. The effects of $\mathrm{pH}$ (2 to 8), initial dye concentration $(25-200 \mathrm{mg} / \mathrm{l})$, amount of WS (1-15 g/l), contact time (10-180 $\mathrm{min}$ ) were performed onto biosorption efficiency. RSM model was also used to reduce experimental data and compare both results. Details of RSM study was given in section 2.6.

\subsection{Modification of WS surface}

Natural WS was not enough to remove ER dye. Modification of WS surface was carried out with mixture of WS loaded HTAB (hegza desil trimetil ammonium brome) at $120 \mathrm{rpm}$ for $2 \mathrm{~h}$ in order to achieve ER removal. Then the sample was centrifuged for $15 \mathrm{~min}$. After washing of sample, it was dried at $100{ }^{\circ} \mathrm{C}$ for $2 \mathrm{~h}$. The following ER dye biosorption experiments were carried out using modified WS. Natural WS was only used for MRGRL biosorption experiments.

\subsection{Isotherm Models and Kinetics}

The equilibrium isotherm belong to specific biosorbent is very essential to the evaluation of biosorption processes (Moussavi et al., 2009). The amount of dye biosorption onto WS was calculated with following mass balance equation:

qe $=\mathrm{V}(\mathrm{Co}-\mathrm{Ce}) / \mathrm{m}$

where qe is the biosorption capacity $(\mathrm{mg} / \mathrm{g}), \mathrm{V}$ is the volume of the dye solution (I), Co and $\mathrm{Ce}(\mathrm{mg} / \mathrm{l})$ are initial and equilibrium dye concentrations, and $\mathrm{m}(\mathrm{g})$ is the amount of of WS.

Experimental results fitted to Langmuir, Freundlich and D$\mathrm{R}$ isotherm models. Langmuir isotherm model explains that monolayer, homogeny adsorption (Crini, 2006; Moussavi et al., 2009).

The equation is given below:

$q e q=\frac{q_{m} b C e q}{1+b C e q}$

$\mathrm{qeq}=\frac{\mathrm{Co}-\mathrm{Ceq}}{\mathrm{X}}$

Where Ceq is the equilibrium liquid concentration $(\mathrm{mg} / \mathrm{l})$, qeq the equilibrium amount adsorbed $(\mathrm{mg} / \mathrm{g})$, qm the maximum adsorption capacity $(\mathrm{mg} / \mathrm{g}), \mathrm{b}$ is the Langmuir constant related to the affinity between sorbent and sorbate (l/mg), $x$ : Amount of biosorbent (g/l).

Freundlich model is an empiric equation for heterogenic surfaces (Shahwan and Erten, 2002).

1

$\mathrm{qe}=\mathrm{k}_{\mathrm{F}} \mathrm{Ce} \mathrm{e}^{\frac{1}{\mathrm{n}}}$ 
Where $\mathrm{k}_{\mathrm{F}}$ and $\mathrm{n}$ are Freundlich constants that are related to the adsorption capacity and intensity, respectively.

Equilibrium data were also fitted to $D-R$ isotherm model in order to determine the nature of biosorption processes as physical or chemical (Sari et al., 2008;).

$q_{e}=q_{m} e^{-\left(\beta \varepsilon^{2}\right)}$

Where qe is the amount of metal ions adsorbed on per unit, weight of biomass (mole/l), qm the maximum biosorption capacity (mole/g), $b$ the activity coefficient related to biosorption mean, free energy $\left(\mathrm{mole}^{2} / \mathrm{J}^{2}\right)$ and $\varepsilon$ is the Polanyi potential $(\varepsilon=R T \ln (1+1 / C \mathrm{C}))$.

The biosorption mean free energy $(E ; \mathrm{kJ} / \mathrm{mole})$ is as follows

$E=\frac{1}{\sqrt{-2 \beta}}$

The biosorption mean free energy gives information about biosorption mechanism. If $E$ value is between 8 and 16 $\mathrm{kJ} / \mathrm{mole}$, the biosorption process follows by chemical ionexchange and if $E<8 \mathrm{~kJ} / \mathrm{mole}$, the biosorption process is of a physical nature (Sawalha et al., 2006).

In this study, data fitted to pseudo-second order rate equation (Aksu, 2001; Basibuyuk and Forster, 2003) and
Intraparticle diffusion model (Weber-Morris Diffusion Model) (Cheng et al., 2008), respectively.

$t / q t=\left[1 / k_{2} q e^{2}\right]+t / q e$

$\mathrm{qt}=\mathrm{ki} \cdot \mathrm{t}^{0,5}+\mathrm{c}$

Where $k_{2}(\mathrm{~g} / \mathrm{mg} \mathrm{min})$ is the rate constant of the secondorder equation, qt $(\mathrm{mg} / \mathrm{g})$ is the amount of biosorption time $\mathrm{t}$ ( $\mathrm{min}$ ) and qe is the amount of biosorption equilibrium $(\mathrm{mg} / \mathrm{g})$. $\mathrm{ki}$ is the intraparticle diffusion rate constant (mg/g. $\min ^{1 / 2}$ ) and $\mathrm{c}$ is intercept $(\mathrm{mg} / \mathrm{g})$. The linear plots of $t / q$ t versus $t$; q versus $t^{0,5}$ show that the pseudosecond order model and intraparticle diffusion model for the biosorption of azo dyes onto WS, respectively.

\subsection{RSM Model}

The removal capacity was chosen as the independent output variable. Total number of 29 experiment were carried out to estimate the 15 coefficients for the removal of MRGRL and ER (Table 2a-2b). Data were analyzed using design program including ANOVA to find out the interaction between the variables and response Surface plots were plotted to study the synergistic effect of variables on the response and also to optimize the removal of dyes. Table 2 shows experimental range and levels of independent variables for MRGRL and ER.

Table 2. Experimental range and levels of independent variables for MRGRL and ER

\begin{tabular}{ccccc}
\hline Variables & \multicolumn{3}{c}{ Range and Levels } \\
\cline { 2 - 5 } Initial pH of solution (pH), A & Low Level (-1) & Center Level (0) & High Level (+1) & $\Delta$ Xia \\
\cline { 2 - 5 } Initial concentration of Dye(Co), B (mg/l) & 2.0 & 5.0 & 8.0 & 200 \\
Dosage (m), C (g) & 0.1 & 112.5 & 1,5 & 87.5 \\
Contact time (tc), D (min) & 10 & 0.8 & 180 & 8.7 \\
\hline
\end{tabular}

astep change values.

Table 2a. Box-Behnken design matrix with three independent variables expressed in coded and natural units for MRGRL

\begin{tabular}{cccccc}
\hline \multirow{2}{*}{ Batch No } & $\begin{array}{c}\text { Initial pH of } \\
\text { solution }(\mathbf{p H})\end{array}$ & $\begin{array}{c}\text { Initial concentration of } \\
\text { MRGRL dye (Co), (mg/l) }\end{array}$ & $\begin{array}{c}\text { Contact time (tc), } \\
\text { (min) }\end{array}$ & $\begin{array}{c}\text { Amount of WS } \\
(\mathbf{m}), \mathbf{( g )}\end{array}$ & MRGRL removal \% \\
\cline { 2 - 7 } & Factor A & Factor B & Factor C & Factor D & \\
\hline 1 & 5 & 112,5 & 180 & 1,5 & 96,84 \\
\hline 2 & 5 & 112,5 & 95 & 0,8 & 94,65 \\
\hline 3 & 5 & 25 & 180 & 0,8 & 93,18 \\
\hline 29 & 2 & 112,5 & 180 & 0,8 & 93,00 \\
\hline
\end{tabular}

Table 2b. Box-Behnken design matrix with three independent variables expressed in coded and natural units for ER

\begin{tabular}{|c|c|c|c|c|c|}
\hline Batch No & $\begin{array}{l}\text { Initial pH of } \\
\text { solution (pH) }\end{array}$ & $\begin{array}{l}\text { Initial concentration of } \\
\text { ER dye (Co), }(\mathrm{mg} / \mathrm{l})\end{array}$ & $\begin{array}{l}\text { Contact time } \\
\text { (tc), (min) }\end{array}$ & $\begin{array}{l}\text { Amount of WS } \\
(\mathrm{m}),(\mathrm{g})\end{array}$ & ERdye removal \% \\
\hline & Factor A & Factor B & Factor C & Factor D & \\
\hline 1 & 5 & 112,5 & 180 & 1,5 & 95,85 \\
\hline 2 & 5 & 112,5 & 95 & 0,8 & 73,63 \\
\hline 3 & 5 & 25 & 180 & 0,8 & 85,56 \\
\hline 29 & 2 & 112,5 & 180 & 0,8 & 88,35 \\
\hline
\end{tabular}

Coded values was given below as a function of dye removal $(Y)$, Where: $p H(A)$, dye concentration(B), dye amount(C) and contact time (D)

\section{Results and discussion}

\subsection{Charecterization of WS}

FTIR spectra shows that WS has different functional groups before and after biosorption of MRGRL (Fig.1 and Table 3). The surface and textural morphology of WS and modified biosorbent by SEM image is illustrated in Fig 2 . 
According to SEM images, biowaste has pore structures. After biosorption, surface of WS filled with dye solution as shown from figure 2.

\subsection{Biosorption Isotherm Models}

Langmuir, Freundlich and D-R models have been used in order to fit the equilibrium data of biosorption process (Fig 3 and Table 3 ). The values of $1<n<10$ show favorable biosorption of MRGRL and ER on the WS (Sarioglu and Atay, 2006). The $E$ value of $D-R$ isotherm model was found to be 7.071 for both dye $\left(R^{2}=0.999\right)$ from Fig.3. The $E$ value $<8$ $\mathrm{kJ} / \mathrm{mole}$, the biosorption process is of a physical nature (Sarioglu et al., 2010).

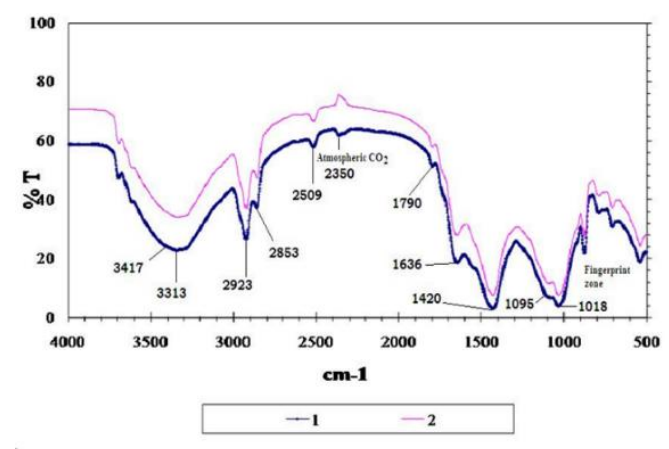

Figure 1. FT-IR spectra of WS and reacted with MRGRL (after biosorption) [1: Dried waste aerobic sludge, natural and 2: After biosorption process)

Table 3. Functional groups for WS biomass (Laurent et al., 2009)

\begin{tabular}{ccc}
\hline Wave number $\left(\mathbf{c m}^{-1}\right)$ & Vibration type & Functional type \\
\hline $3200-3400$ & Stretching vibration of $\mathrm{OH}$ & OH into polymeric compounds \\
\hline 2930 & Asymmetric stretching & \\
\hline 2845 & Vibration of $\mathrm{CH}_{2}$ & \\
\hline & Symmetric stretching & Carboxylic acids \\
\hline 1720 & Vibration of $\mathrm{CH}_{2}$ & Proteins (peptidic bond) \\
\hline $1640-1660$ & Stretching vibration of $\mathrm{C}=\mathrm{O}($ epaulement) & Proteins (peptidic bond) \\
\hline $1550-1560$ & Stretching vibration of $\mathrm{C}=\mathrm{O}$ and $\mathrm{C}=\mathrm{N}$ (amide I) & Carboxylic acids \\
\hline 1455 & Stretching vibration of $\mathrm{C}-\mathrm{N}$ and deformation vibration of $\mathrm{N}$ - \\
$\mathrm{H}$ (amide II) & Phenols \\
\hline 1240 & Deformation vibration of $\mathrm{CH} \mathrm{H}_{2}$ & Polysaccharides \\
\hline $1130-1160$ & Deformation vibration of $\mathrm{C}=\mathrm{O}$ & \\
\hline $1040-1070$ & Stretching vibration $\mathrm{OH}$ & Phosphate or Sulphur functional \\
\hline$<1000$ & Stretching vibration $\mathrm{C}-\mathrm{O}-\mathrm{C}$ & groups \\
\hline
\end{tabular}

Table 3 a). Isotherm constants for Langmuir, Freundlich and D-R models (MRGRL dye)

\begin{tabular}{|c|c|c|c|c|c|c|c|c|c|c|}
\hline & \multicolumn{3}{|c|}{ Langmuir } & \multicolumn{3}{|c|}{ Freundlich } & \multicolumn{4}{|c|}{ D-R } \\
\hline & $\frac{q m}{(\mathrm{mg} / \mathrm{g})}$ & $\frac{b}{(1 / m g)}$ & $R^{2}$ & $\mathrm{k}_{\mathrm{F}}(\mathrm{l} / \mathrm{g})$ & $\mathrm{n}$ & $\mathrm{R}^{2}$ & $\mathrm{q}_{\mathrm{m}}(\mathrm{mol} / \mathrm{g})$ & $\frac{\mathrm{B}}{\left(\mathrm{mol}^{2} / \mathrm{KJ}^{2}\right)}$ & $\frac{E}{(\mathrm{kj} / \mathrm{mol})}$ & $\mathrm{R}^{2}$ \\
\hline MRGRL & 58.82 & 0.046 & 0.988 & 2.6792 & 1.171 & 0.998 & 0.000774 & -0.010 & 7.071 & 0.999 \\
\hline
\end{tabular}

Table 3 b). Isotherm constants for Langmuir, Freundlich and D-R models (ER dye)

\begin{tabular}{|c|c|c|c|c|c|c|c|c|c|c|}
\hline & \multicolumn{3}{|c|}{ Langmuir } & \multicolumn{3}{|c|}{ Freundlich } & \multicolumn{4}{|c|}{ D-R } \\
\hline & $\begin{array}{c}\mathrm{qm} \\
(\mathrm{mg} / \mathrm{g})\end{array}$ & $\frac{b}{(L / m g)}$ & $\mathrm{R}^{2}$ & $\mathrm{k}_{\mathrm{F}}(\mathrm{L} / \mathrm{g})$ & $\mathrm{n}$ & $\mathrm{R}^{2}$ & $\mathrm{q}_{\mathrm{m}}(\mathrm{mol} / \mathrm{g})$ & $\begin{array}{c}\mathrm{B} \\
\left(\mathrm{mol}^{2} / \mathrm{KJ}^{2}\right) \\
\end{array}$ & $\begin{array}{c}\mathrm{E} \\
(\mathrm{kj} / \mathrm{mol})\end{array}$ & $\mathrm{R}^{2}$ \\
\hline $\begin{array}{c}\text { ER (Modified } \\
\text { WS) }\end{array}$ & 25,641 & 0,0393 & 0.999 & 1,312 & 1,441 & 0,984 & 0,000077 & $-0,010$ & 7,071 & 0.997 \\
\hline
\end{tabular}




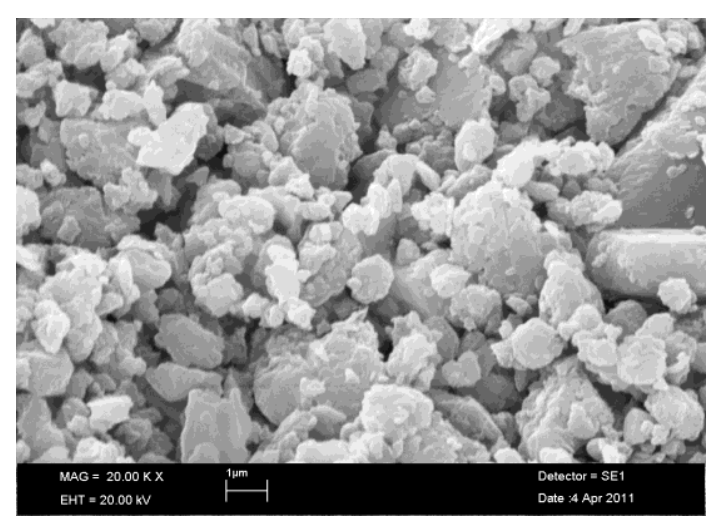

(a)

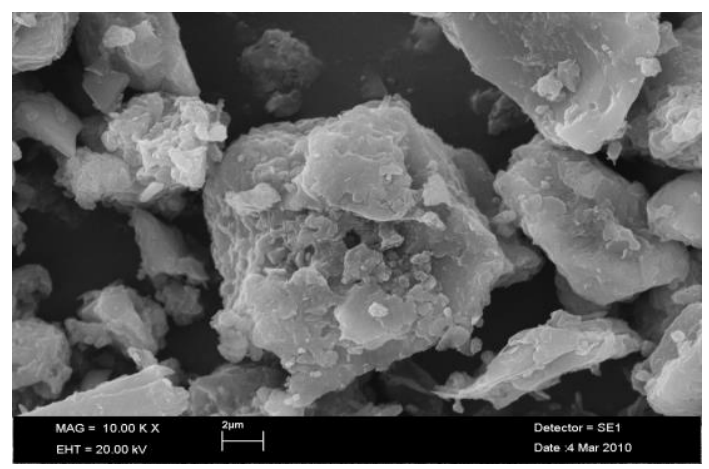

(c)

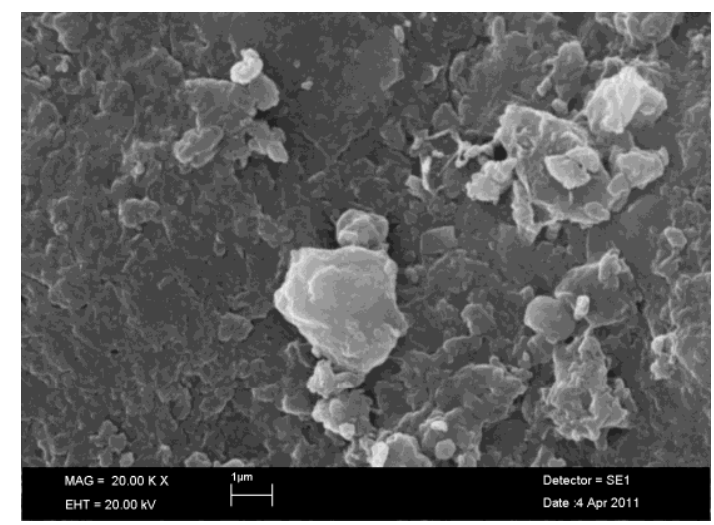

(b)

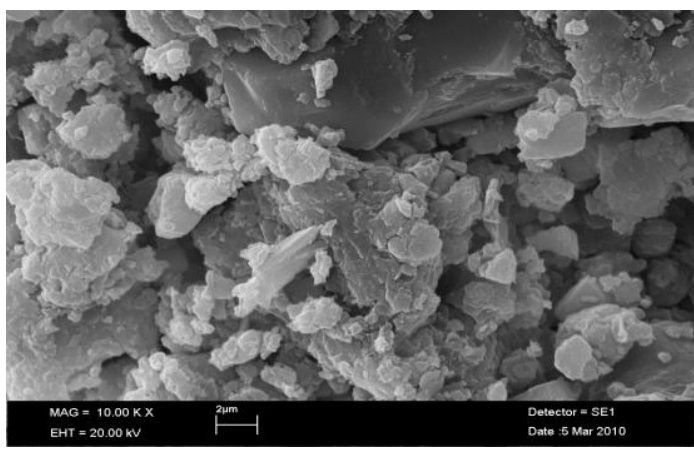

(d)

Figure 2. MRGRL: SEM images of WS before (a) and after biosorption (b). ER: SEM images modified WS before (c) and (d) after biosorption

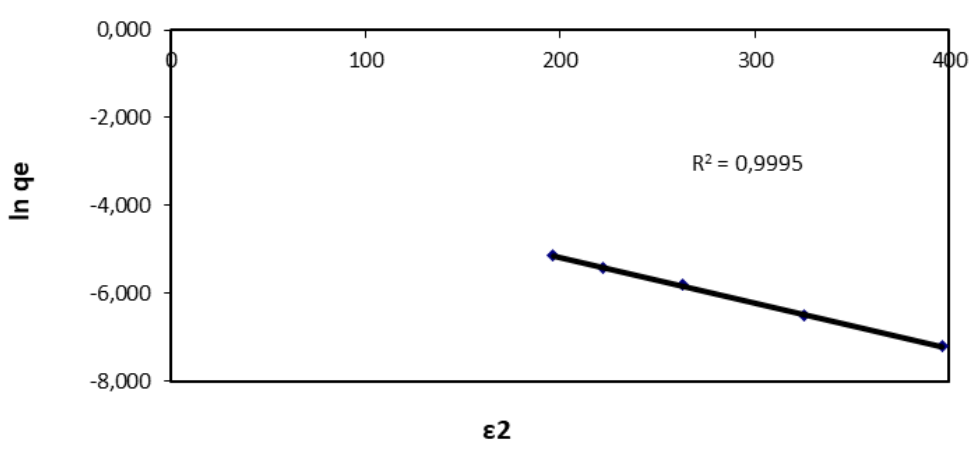

Figure 3. D-R isotherm models for biosorption of MRGRL onto WS

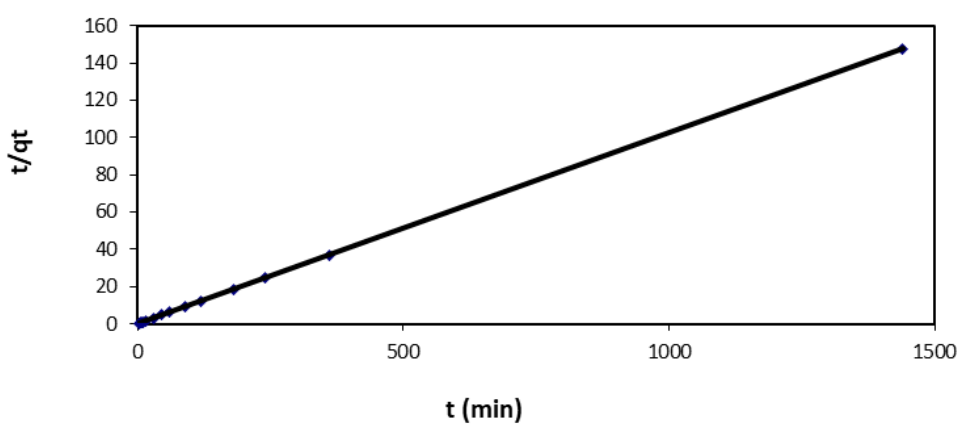

Figure 4 Pseudo-second-order kinetic plot for the biosorption of MRGRL onto WS biomass 


\subsection{Biosorption Kinetics}

Pseudo-second-order kinetic model was used to investigate the biosorption mechanism. The calculated qe value from the second-order kinetic model agreed with the experimental value of maximum biosorption amount (qeq). Therefore, pseudo-second-order kinetic model was suitable for biosorption kinetics for MRGRL and ER removal using WS and modified WS (Fig. 4 and Table 4). The intraparticle diffusion model was used to predict the ratecontrolling step. From the figure 5, multi-linarites were observed indicating with three stage diffusion. The first stage is external mass transfer, followed by intraparticle diffusion in macro, meso, and micropore and finally it reaches equilibrium stage. The second stage could be controlled by intraparticle diffusion.

Table 4a. Pseudo-second-order kinetic constants for the biosorption of MRGRL onto WS

\begin{tabular}{cccccc}
\hline & qe,eq (mg/g) & k2,ad & qe,teo (mg/g) & h (mg/g.min) & $\mathbf{R}^{\mathbf{2}}$ \\
\hline MRGRL & 9.75 & 0.1107 & 9.804 & 10.6403 & 1.000 \\
\hline
\end{tabular}

Table 4b. Pseudo-second-order kinetic constants for the biosorption of ER onto modified WS

\begin{tabular}{ccccc}
\hline & qe,eq (mg/g) & k2,ad & qe,teo (mg/g) & h (mg/g.min) \\
\hline$E R$ & 8.75 & 0.0069 & 9.709 & 0.646 \\
\hline
\end{tabular}

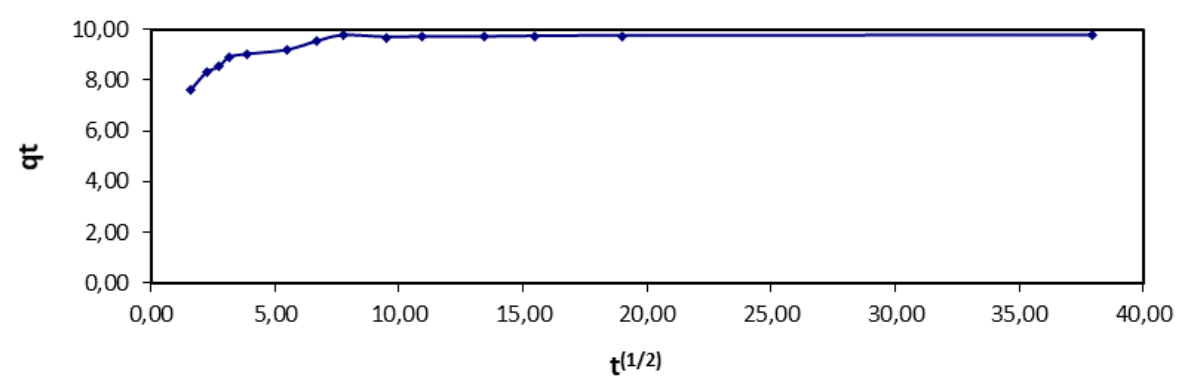

Figure 5. Intraparticle diffusion model for MRGRL dye removal

\subsection{RSM Model Results}

The regression model equation obtained is shown in Equation for MRGRL and ER, respectively.

(\%)MRGRL Removal=+94.94+1.18*A-1.25*B $+5.23 * \mathrm{C}$ $+21.68 * D+1.05 * A * B-1.58 * A * C+0.68 * A * D+3.65 * B * C$ $+0.67 * B * D-5.04 * C * D-1.96 * A 2-0.17 * B 2-5.35 * C 2-18.34 *$ D2

(\%)ERRemoval $=+80.31-5.53 * A-7.20 * B+10.44 * C+18.44 * D-$ 2.72*A*B-7.20*A*C-1.33*A*D+0.22*B*C-1.63*B* $D+11.46 * C * D-8.81 * A 2+4.59 * B 2-13.46 * C 2-9.26 * D 2$

There is a good correlation between predicted and observed values. Fig 6 and 7.

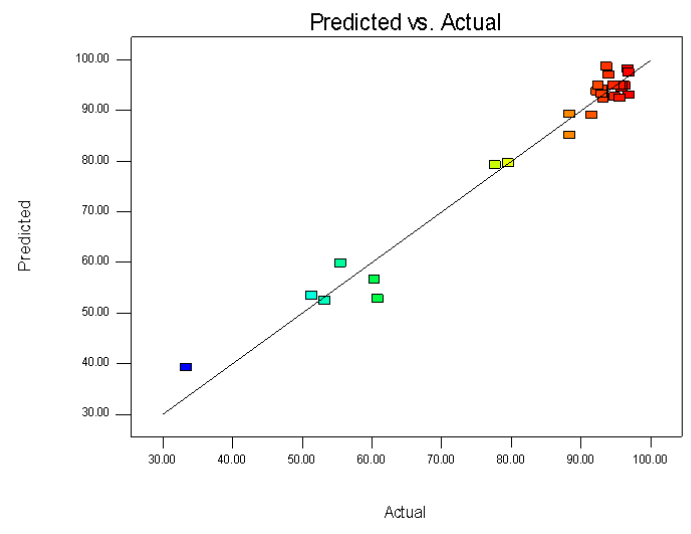

Figure 6. Correlation between pridected and observed data for MRGRL
Based on $R^{2}$ as shown in figures $(6,7)$ there is good corelation between observed and predicted values.

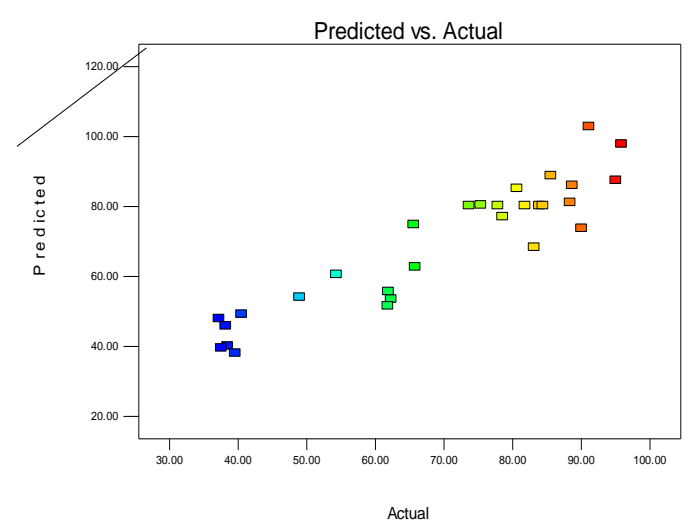

Figure 7. Correlation between pridected and observed data for $E R$

\subsection{Desorption and Effects on Ionic Strength on Biosorption}

Desorption study was performed using $0,1 \mathrm{M} \mathrm{HCl}$ and $\mathrm{NaOH}$ for selected times. Desorption efficiency was low for both dyes (Table $5 a$ and $b$ ).

$\mathrm{NaCl}$ was selected for ionic strength experiments. Effect of $\mathrm{NaCl}$ ion to dye removal efficiency between 0,5-1 mole was not important for both dye. 
Table 5a. Desorption study for MRGRL

\begin{tabular}{ccccccc}
\hline \multirow{2}{*}{ t(time) } & \multicolumn{3}{c}{ HCl } & & \multicolumn{3}{c}{ NaOH } \\
\cline { 2 - 7 } & ABS & Ce & \%Des & ABS & Ce & \%Des \\
\hline 15 min & 0,338 & 3,063 & 3,16 & 0,091 & 0,463 & 0,47 \\
\hline $90 \mathrm{~min}$ & 0,276 & 2,411 & 2,47 & 0,132 & 0,895 & 0,90 \\
\hline $180 \mathrm{~min}$ & 0,314 & 2,811 & 2,89 & 0,121 & 0,779 & 0,79 \\
\hline $1440 \mathrm{~min}$ & 0,308 & 2,747 & 2,82 & 0,195 & 1,558 & 1,58
\end{tabular}

Table 5b. Desorption study for ER

\begin{tabular}{|c|c|c|c|c|c|c|}
\hline \multirow{2}{*}{$\mathbf{t}$ (time) } & \multicolumn{3}{|c|}{$\mathrm{HCl}$} & \multicolumn{3}{|c|}{$\mathrm{NaOH}$} \\
\hline & ABS & $\mathrm{Ce}$ & \%Des & ABS & $\mathrm{Ce}$ & \%Des \\
\hline $15 \mathrm{~min}$ & 0,033 & 2,44 & 1,41 & 0,122 & 7,17 & 2,72 \\
\hline $90 \mathrm{~min}$ & 0,151 & 6,11 & 3,31 & 0,164 & 8,61 & 5,42 \\
\hline $180 \mathrm{~min}$ & 0,173 & 8,50 & 5,49 & 0,255 & 12,72 & 7,58 \\
\hline $1440 \mathrm{~min}$ & 0,226 & 10,28 & 7,76 & 0,284 & 14,39 & 9,21 \\
\hline
\end{tabular}

Table 6. Effect of $\mathrm{NaCl}$ on dye removal efficiencies

\begin{tabular}{ccc}
\hline & \multicolumn{2}{c}{ Removal efficiency (\%) } \\
\hline $\mathbf{N a C l}\left(\mathbf{m o l e ~ L ~}^{-\mathbf{1}}\right)$ & E.RED-Modified WS & MRGRL-WS \\
\hline 0 & 95,34 & 97,00 \\
\hline 0,01 & 94,55 & 97,16 \\
\hline 0,05 & 93,24 & 96,17 \\
\hline 0,1 & 92,12 & 94,89 \\
\hline 0,5 & 91,00 & 94,07 \\
\hline 1 & 90,39 & 92,71
\end{tabular}

\section{Conclusion}

The optimum experimental conditions were found to be $\mathrm{pH}=5, \mathrm{Co}=112.5 \mathrm{mg} / \mathrm{l}, \mathrm{tc}=180 \mathrm{~min}$. and $\mathrm{m}=15 \mathrm{~g} / \mathrm{l}$ for dyes and MRGRL and ER removal was determined as about $97 \%$ and $95.85 \%$, respectively. The results clearly showed that amount of WS and contact time are the most important parameters for color removal. FTIR and SEM images were used to understand morphology and structural character of natural WS and modified WS and after biosorption process. The experimental equilibrium data fitted to Freundlich, Langmuir isotherm models. Both models were suitable for experimental results. In addition, in order to determine type of biosorption D-R isotherm model was used. Pseudosecond order and intraparticle models were suitable for biosorption kinetics.

WS (waste sludge), natural or modified, one of the low-cost biosorbent, can be used for removal of azo dye from wastewaters and it may be an alternative to expensive adsorbent materials.

\section{Acknowledgement}

This work is supported by the Scientific Research Project Fund of Cumhuriyet University under the project number M430.

\section{References}

Aksu Z. (2001), Biosorption of Reactive Dyes by Dried Activated Sludge: Equilibrium and Kinetic Modelling, Biochemical Engineering Journal, 7, 79-84.

Aksu Z. (2005), Application of Biosorption for the Removal of Organic Pollutants: a Review, Process Biochemistry, 40, 997-1026.
Al-Qodah Z. (2000), Adsorption of Dyes Using Shale Oil Ash, Water Res, 34(17), 4295-4303.

Basıbuyuk M. and Forster C.F. (2003), An Examination of Adsorption Characteristics of Basic Dye on to Live Activated Sludge Syste., Process Biochem, 38, 1311-1316.

Beydilli M.I., Pavlostathis S.G. and Tincher W.C. (2000), Biological Decolorization of the Azo Dye Reactive Red 2 Under Various Oxidation-Reduction Conditions, Water Environ. Res, 72(6), 698-705.

Cheng W., Wang S.G., Lu L., Gong W.X., Liu X.W., Gao B.Y. and Zhang H.Y. (2008), Removal of Malachite Gren (MG) from Aqueous Solutions by Native and Heat-treated Anaerobic Granular Sludge, Biochemical Engineering Journal, 39, 538-546.

Crini G. (2006), Non-Conventional Low-Cost Adsorbents for Dye Removal: A Review, Bioresource Technology, 97, 1061-1085.

El-Geundi M.S. (1991), Homogeneous Surface Diffusion Model for the Adsorption of Basic Dyestuffs onto Natural Clay in Batch Adsorbers, Adsorp. Sci. Technol, 8, 217-225.

Forgacs E., Cserhati T. and Oros G. (2004), Removal of Synthenic Dyes from Wastewaters: a Review, Environment International, 30, 953-971.

Han. R., Wang. Y.F., Han. P., Shi. J., Yang. J. And Lu Y.S. (2006) Removal of Methylene Blue From Aqueous Solution by Chaff in Batch Mode, Journal of Hazardous Materials B., 137, 550-557.

Juang R.S., Tseng R.L., Wu F.C. and Lee S.H. (1997), Adsorption behavior of reactive dyes from aqueous solutions on chitosan, J. Chem. Technol. Biotechnol, 70(4), 391-399.

Kargi F. and Ozmihci S. (2004), Biosorption Performance of Powdered Activated Sludge for Removal of Different Dyestuffs, Enzyme and Microbial Tech, 35, 267-271. 
Laurent J., Casellas M., Pons M.N. and Dagot C. (2009), Flocs Surface Functionality Assessment of Sonicated Activated Sludge in Relation with Physico-Chemical Properties, Ultrasonics Sonochemistry, 16, 488-494

Mckay G., Ramprasad G. and Mowli P.P. (1986), Equilibrium Studies For the Adsorption of Dyestuffs From Aqueous Solution by Low-Cost Materials, Water, Air and Soil Poll, 29(3), 273-283.

Meshko V., Markovska L., Mincheva M. and Rodrigues A.E. (2001), Adsorption of Basic Dyes on Granular Activated Carbon and Natural Zeolite, Water Res, 35(14), 3357-3366.

Moussavi G. and Mahmoudi M. (2009), Removal of Azo and Anthraquinone Reactive Dyes from Industrial Wastewaters Using MgO Nanoparticles, Journal of Hazardous Materials, 168, 806-812.

Murugesan K., Dhamija A., Nam I.H., Kim Y.M. and Chang Y.S. (2007), Decolourization of Reactive Black 5 by Laccase: Optimization by Response Surface Methodology, Dyes and Pigments, 75, 176-184.

Pagga U. and Browb D. (1986), The Degradation of Dye-Stuffs, Part II: Behaviour of Dyestuffs in Aerobic Biodegradation Tests, Chemosphere, 15(4), 479-491.

Panswad T. and Luangdilok W. (2000), Decolorization of Reactive Dyes with Differenr Molecular Structures Under Different Environmental Conditions, Water Res, 34(17), 4177-4184.

Rytwo G., Nir S., Crepsin M. and Margulies L. (2000), Adsorption and Interactions of Methyl Green with Monotmorillonite and Sepiolite, J. Colloid Interface Sci, 222(1), 12-19.

Sari A., Mendil D., Tuzen M. and Soylak M. (2008), Biosorption of $\mathrm{Cd}$ (II) and $\mathrm{Cr}$ (III) from Aqueous Solution by Moss (Hylocomium splendens) Biomass: Equilibrium, Kinetic and Thermodynamic Studies, Chemical Engineering Journal, 144, 1-9.

Sarioglu M. and Atay U.A. (2006), Removal of Methylene Blue by Using Biosolid, Global Nest Journal, 8, 113-120.

Sarioglu M. and Bisgin T. (2007), The Removal of C.I. Basic Red 46 in a Mixed Methanogenic Anaerobic Culture, Dyes and Pigments, 74, 223-229.

Sarioglu M., Deniz C. and Guler U.A. (2010), Removal of Cationic Dye (Methylene Blue) Using Yeast Culture ( $K$. Marxianus): Kinetics and Equilibrium Studies, ORBIT Conference 29 June-3 July 2010 Crete-Greece, Oral presentation.

Sawalha M.F., Videa J.R.P., Gonzalez J.R. and Gardea-Torresdey J.L. (2006), Biosorption of $\mathrm{Cd}(\mathrm{II}), \mathrm{Cr}(\mathrm{III})$, and $\mathrm{Cr}(\mathrm{VI})$ by Saltbush (Atriplex Canescens) Biomass: Thermodynamic and Isotherm Studies, J. Colloid Interface Sci., 300, 100-104.

Shahwan T. and Erten H.N. (2002), Thermodynamic Parameters of $\mathrm{Cs}^{+}$Sorption on Natural Clays, J. Radio Analytical Nuclear Chem., 253(1), 115-120.

Sharma P., Singh L. and Dilbaghi N. (2009), Optimization of Process Variables for Decolorization of Disperse Yellow 211 by Bacillus subtilis Using Box-Behnken Design, Journal of Hazardous Materials, 164, 1024-1029.

Sun G. and Xu X. (1997), Sunflower Stalks as Adsorbents for Color Removal from Textile Wastewater, Ind. Eng. Chem. Res, 36, 808-812.

Volesky B. (1990) Biosorption and Biosorbents In:Volesky b, Editor. Biosorption of Heavy Metals Florida: CRC pres, 3-5.

Wang J. and Chen C. (2006), Biosorption of Heavy Metals by Saccharomyces Cerevisiae. A Review, Biotechnology Advances, 24, 427-451.
Wu J., Eitman M.A. and Law S.E. (1998), Evalution of Membrane Filtration and Ozonation Processes for Treatment of Reactive Dye Wastewater, J. Environ. Eng, 12(3), 272-277.

Yetilmezsoy K., Demirel S. and Vanderbei R.J. (2009), Response Surface Modelling of $\mathrm{Pb}$ (II) Removal from Aqueous Solution by Pistacia vera L.: Box-Behnken Experimental Design, Journal of Hazardous Materials, 171, 551-562.

Zoolinger H. (1991) Color Chemistry, VCH Publishers, second ed, New York. 